\title{
Antibacterial and bactericidal activity of nitric oxide-releasing natural zeolite
}

\author{
Güler Narin *, Çisem Bulut Albayrak, Semra Ülkü \\ Department of Chemical Engineering, Izmir Institute of Technology, Urla 35430 Izmir, Turkey
}

\section{A R T I C L E I N F O}

\section{Article history:}

Received 16 February 2010

Received in revised form 13 October 2010

Accepted 14 October 2010

Available online 12 November 2010

\section{Keywords:}

Clinoptilolite-rich natural zeolite

Nitric oxide adsorption

Antibacterial activity

Bactericidal activity

Nitric oxide release kinetics

\begin{abstract}
A B S T R A C T
The zeolitic tuff from Gördes (Western Anatolia) was used as adsorbent for nitric oxide (NO) storage and release purposes. The NO loading of the zeolite was performed under $20 \mathrm{~mL} \mathrm{~min}{ }^{-1} \mathrm{NO}$ flow at $30^{\circ} \mathrm{C}$ and then the zeolite was purged with inert gas in order to remove the species that were reversibly adsorbed and in the gas phase (desorption). The total and reversible adsorption capacities of the zeolite were determined from the adsorption and desorption breakthrough curves, respectively. The NO-loaded zeolite exhibited antibacterial and bactericidal activities against Gram-negative (Escherichia coli) and Gram-positive bacteria (Bacillus subtilis) under physiological conditions. From the NO release kinetics, the diffusion coefficient of NO in the zeolite particle was determined.
\end{abstract}

(C) 2010 Elsevier B.V. All rights reserved.

\section{Introduction}

Nitric oxide (NO) is synthesized throughout the body by cells such as endothelial cells, macrophages, neutrophiles, fibroblasts, keratinocytes. It is involved in a number of physiological functions in the body such as blood pressure regulation (Kelm, 2003), neurotransmission (Yun et al., 1996), inhibition of platelet adhesion (Riddell and Owen, 1999), vasodilatation (Moncada et al., 1991), wound healing (Witte and Barbul, 2002) and nonspecific immune response to infection (Sasaki et al., 1998). There are direct chemical reactions in which NO interacts directly with biological molecules. Such reactions are generally rapid, require low concentrations of NO and most likely account for majority of the physiological effects of NO. The indirect effects are derived from the reaction of NO with either superoxide or oxygen, which yields reactive nitrogen oxide species (RNOS) such as peroxynitrite. The oxidative and nitrosative stress generated by RNOS may result in damage to DNA, proteins, and/or cells. The indirect effects are often associated with the pathophysiological effect of NO (Fang, 1997; Wink and Mitchell, 1998; Mateo and De Artinano, 2000).

NO-related antimicrobial activity has been demonstrated against a broad range of pathogenic microorganisms including viruses, bacteria, fungi, and parasites (De Groote and Fang, 1995). The antimicrobial effect of NO was primarily due to its reactive byproducts (Fang, 1997). Since NO is a small, relatively nonpolar, uncharged, lipophilic molecule, it crosses cell membranes readily. The diffusion of NO through the membranes is similar to that of $\mathrm{O}_{2}$ (Denicola et al., 1996). NO and $\mathrm{O}_{2}$ tend to concentrate in cell membranes, accelerate oxidation of

\footnotetext{
* Corresponding author. Tel.: + 90232 7506672; fax: +90 2327506645 E-mail address: gulernarin@gmail.com (G. Narin).
}

NO to dinitrogen trioxide $\left(\mathrm{N}_{2} \mathrm{O}_{3}\right)$ and generated higher nitrosative stress within and near the bacterial cell membrane (Wink and Mitchell, 1998; Fang, 1997, 2004; Stamler et al., 2001). Peroxynitrite formed as a result of reaction of NO with superoxide $\left(\sigma_{2}\right)$ is an oxidizing agent that can disrupt the structural integrity of bacterial cell membranes (Wink and Mitchell, 1998). Nitrosation of both cell surface proteins and intracellular proteins (including enzymes) by RNOS has been shown to alter protein function and cause bacterial cell death (Fang, 1997).

It was stated that nitrite $\left(\mathrm{NO}_{2}\right)$, a stable end product of $\mathrm{NO}$ oxidation, can be toxic to cells (Menzel, 1993). The formation of $\mathrm{NO}_{2}$ is dependent on the concentration of the reactants ( $\mathrm{NO}$ and $\mathrm{O}_{2}$ ) as well as the time available for the reaction (Hoehn et al., 1998). The major oxidation reactions of $\mathrm{NO}$ by $\mathrm{O}_{2}$ in an aqueous solution are shown below (Wang and Deen, 2003):

$$
\begin{aligned}
& 2 \mathrm{NO}+\mathrm{O}_{2} \rightarrow 2 \mathrm{NO}_{2} \\
& \mathrm{NO}+\mathrm{NO}_{2} \rightarrow \mathrm{N}_{2} \mathrm{O}_{3} \\
& \mathrm{~N}_{2} \mathrm{O}_{3}+\mathrm{H}_{2} \mathrm{O} \rightarrow 2 \mathrm{NO}_{2}^{-}+2 \mathrm{H}^{+} .
\end{aligned}
$$

These reactions can be simplified to:

$4 \mathrm{NO}+\mathrm{O}_{2}+\mathrm{H}_{2} \mathrm{O} \rightarrow 4 \mathrm{NO}_{2}^{-}+4 \mathrm{H}^{+}$.

Application of gaseous NO as an antibacterial agent was investigated in a specially designed exposure chamber on the plated bacterial cells. The continuous exposure to $160 \mathrm{ppm}$ gaseous NO for $5 \mathrm{~h}$ resulted in a bactericidal effect of $84 \%$ and $98 \%$ on Pseudomonas 
aeruginosa and Staphylococcus aureus, respectively. No toxic effects were observed on dermal fibroblast proliferation at concentrations up to 400 ppm gaseous NO for $48 \mathrm{~h}$ (Ghaffari et al., 2005).

Since NO is an extremely reactive gas, it is difficult to administer it for therapeutic purposes, therefore recent researches have focused on development of suitable vehicles for NO storage and delivery. Different NO-releasing polymers, sol-gel arrays and silica nanoparticles were synthesized and characterized as antimicrobial coatings on implants. These coatings were efficient in reduction of bacterial adhesion (Pseudomonas aeruginosa, Staphylococcus aureus, Staphylococcus epidermidis) and related infection (Dobmeier and Schoenfisch, 2004; Nablo et al., 2005; Hetrick et al., 2008). McKinlay and colleagues (2008) synthesized porous polymeric metal organic frameworks (MOFs) (Co-MOF and Ni-MOF) and measured their NO adsorption capacities gravimetrically at room temperature as about $7 \mathrm{mmol} \mathrm{g}^{-1}$. It was shown that each coordinatively unsaturated metal atom sites on the walls of the pores in the MOFs was coordinated to one NO molecule. All stored NO was released upon exposure of the MOFs to moisture even after the MOFs have been stored for several months. The released NO caused relaxation of porcine arterial tissue and prevented inflammatory responses in human tissue (McKinlay et al., 2008). Since the effects of the released NO remain localized near the coating/blood or tissue interface, the potentially detrimental side effects encountered in other systemically administered therapies can be prevented (Kelm and Schrader, 1988; Kelm and Yoshida, 1996). NO released from the coatings on implants may also enhance wound healing (Trowbridge and Emling, 1997) and promote angiogenesis (Ziche et al., 1994; Fukumura and Jain, 1998).

Recently synthetic zeolites were applied for NO delivery purposes. Wheatley and colleagues (2006) compared the amount of NO released from Zeolite-A exchanged with different metals $\left(\mathrm{Na}^{+}, \mathrm{Ni}^{2+}\right.$, $\mathrm{Cu}^{2+}, \mathrm{Co}^{2+}$, and $\mathrm{Mn}^{2+}$ ) and found that Co-exchanged zeolite released the highest amount of NO. The amount and rate of NO release were found to be dependent on the chemical composition of the zeolite. The total and irreversible adsorption capacities of $\mathrm{Co}^{-}$ exchanged Zeolite-A for NO were measured gravimetrically at $25^{\circ} \mathrm{C}$ as $1.7 \mathrm{mmol} \mathrm{g}^{-1}$ and approximately $1.3 \mathrm{mmol} \mathrm{g}^{-1}$, respectively. The total adsorption capacity corresponds to the sum of the reversible and irreversible adsorption capacities. The reversibly adsorbed NO is weakly adsorbed so it is desorbed by gradually decreasing the system pressure to $2 \times 10^{-2}$ mbar at $25^{\circ} \mathrm{C}$. The irreversibly adsorbed NO is relatively strongly held (primarily chemisorbed) and so it is not spontaneously desorbed from the zeolite due to decrease in the NO pressure. The release of the 'irreversibly' adsorbed NO from the zeolite was performed under $200 \mathrm{~mL} \mathrm{~min}^{-1}$ flow of argon with relative humidity of $11 \%$. The total amount of NO released per gram of zeolite was approximately $1 \mathrm{mmol} \mathrm{g}^{-1}$. The relative humidity of the argon was found to control the NO release rate. For release in aqueous environment at biologically relevant conditions of temperature and $\mathrm{pH}$, the zeolite samples were prepared as pressed disks with small amounts of powdered polymers (PTFE and PDMS) as binders and subsequently dehydrated and loaded with NO. It was found that the amount and rate of NO release were reduced when the zeolite was blended with the polymers. Furthermore, the nature of the polymer also had an influence on the NO release rate. The NO released from the zeolite/PTFE disks upon contact with platelet-rich plasma (PRP) at $37{ }^{\circ} \mathrm{C}$ inhibited platelet aggregation and adhesion of human platelets in vitro (Wheatley et al., 2006).

In another study, it was shown that LTA and FAU zeolites exchanged with transition metal cations $\left(\mathrm{Co}^{2+}, \mathrm{Mn}^{2+}, \mathrm{Zn}^{2+}\right.$ and $\left.\mathrm{Cu}^{2+}\right)$ could store and deliver $1.2-2.7 \mathrm{mmol} \mathrm{NO} \mathrm{g}^{-1}$ zeolite. The Co exchanged LTA released the greatest amount of $\mathrm{NO}$ whereas the sodium form released the least amount. The stored NO was released by exposing the zeolites to argon flow saturated with water vapor. The NO release took about $10 \mathrm{~h}$. It was stated that the amount and rate of NO release depended on the type and amount of the metal present. The NO releasing Co-LTA/PTFE discs (75:25 weight \%) completely inhibited platelet aggregation and adhesion (Xiao et al., 2007).

More recently, Fox et al. (2010) showed bactericidal activity of NOreleasing $\mathrm{Zn}^{2+}$-exchanged LTA zeolite against clinically relevant strains of bacteria, namely Pseudomonas aeruginosa, methicillinsensitive and methicillin-resistant Staphylococcus aureus and Clostridium difficile. The $\mathrm{Zn}^{2+}$-exchanged zeolite powder was loaded with NO and pressed into discs composed of equal amounts of the zeolite and polytetrafluoroethylene (PTFE). The discs released high concentrations of NO over approximately $1 \mathrm{~h}$ on contact with $5 \%$ LB broth: phosphate-buffered saline (PBS) solution. The discs exhibited bactericidal activity against the bacterial strains. The NO-loaded $\mathrm{Zn}^{2+}$ exchanged zeolite exhibited significantly higher bactericidal activity as compared to the NO-free $\mathrm{Zn}^{2+}$-exchanged zeolite. The mechanism of the observed bactericidal effect was associated with the release of high concentrations of NO. The bactericidal activity was much quicker than those due to the release of metal ions from the zeolite. The development of these materials as antimicrobial coatings for use in medical devices was also discussed in the article (Fox et al., 2010).

Clinoptilolite-rich natural zeolites have been applied for drug delivery purposes (Rodriguez-Fuentes et al., 1997; Rivera et al., 1998, 2003; Concepción-Rosabal et al., 1997, 2005; Lam et al., 1998; Carballo et al., 2001; Farías et al., 2003; Rivera and Farías, 2005) and as a potential adjuvant in anticancer treatment (Seidel et al., 1997; Parlat et al., 1999; Pavelic et al., 2001, 2002). Recently, the clinoptilolite-rich natural zeolite from Western Anatolia and its acid-modified and ionexchanged forms were investigated for its thermal stability, antibacterial activity, water vapor, carbon dioxide and carbon monoxide adsorption and diffusion properties (Top, 2001; Top and Ülkü, 2004; Çakıcıoğlu-Özkan and Ülkü, 2004, 2008; Narin, 2001; Narin et al., 2004; Akdeniz and Ülkü, 2007, 2008). Regarding the importance of storage and release of NO, a microporous natural adsorbent with high pore volume can be a good candidate for this purpose. In the present study, applicability of local clinoptilolite-rich natural zeolite for storage and release of NO for medical purposes was investigated. Special interest has been devoted to clinoptilolite-rich natural zeolite due to the estimated reserve of 50 billion tons in Gördes basin (Western Anatolia) with high mineral purity and homogeneity (Esenli, 2002).

\section{Materials and methods}

\subsection{Preparation and characterization of the natural zeolite}

The zeolitic tuff from Gördes (Western Anatolia) was crushed, ground and wet sieved to the particle diameter range of 75-150 $\mu \mathrm{m}$. After that the particles were washed with hot distilled water in the solid/liquid ratio of $1 / 20$ (S/L ratio: g zeolite $\mathrm{mL}^{-1}$ solution) on a hot plate under mechanical stirring. The washing process was repeated once more and the remaining solid was dried in an oven at $65{ }^{\circ} \mathrm{C}$ for $24 \mathrm{~h}$. The zeolite particles obtained were labeled as "NZ".

\subsubsection{Powder X-ray diffraction analysis}

The powder X-ray diffraction pattern of NZ was recorded on a powder diffractometer (X'Pert Pro, Philips) equipped with Ni filtered CuK $\alpha$ radiation source $(\lambda=1.540560 \AA)$ over the $2 \theta$ range of $5^{\circ}$ to $50^{\circ}$ at a 10.15 second measurement time per step and a step size of $0.01671^{\circ}$. The X-ray source was operated at $40 \mathrm{~mA}$ and $45 \mathrm{kV}$. Prior to the analysis, NZ was gently ground into a fine powder and packed into an aluminum sample holder.

The qualitative crystalline mineralogical composition of NZ was determined by matching the diffractogram of NZ to those in the International Centre for Diffraction Data database (JCPDS-ICDD PDF-1 database). The quantitative mineralogical analysis was carried out by the application of the method based on the multiple analytical XRD lines (Nakamura et al., 1992). The clinoptilolite standard minerals 
(27031, Castle Creek, Idaho and 27023, Hector, California; referred as Idaho and California, respectively) were used in the quantitative mineralogical analysis.

\subsubsection{Elemental analysis}

The elemental composition of NZ was determined by an inductively coupled plasma atomic emission spectrometer with axial plasma (Liberty Series II ICP-AES, Varian).NZ was treated with an alkali borate fusion flux (anhydrous lithium tetraborate) and dissolved in $1.6 \mathrm{M} \mathrm{HNO}_{3}$ prior to the analysis.

\subsubsection{Scanning electron microscopy-Energy dispersive X-ray analysis (SEM-EDX)}

The particle, crystal and surface morphology of NZ were investigated on a scanning electron microscope (SEM) (XL-30S FEG SEM, Philips). The particles were mounted directly on a carbon tape before the analysis. The elemental composition of the surface of NZ was analyzed via energy dispersive X-ray spectroscopy (EDX) which is combined with the SEM. The EDX analyses were carried out on six randomly chosen regions of about $100 \mu \mathrm{m} \times 50 \mu \mathrm{m}$ area on the particle surface. The energy of the beam was $10 \mathrm{kV}$. Regarding the depth of X-rays generated on the particle surface $(2 \mu \mathrm{m})$ (http:// www.uksaf.org/tech/edx.html) and the size of the particles, the EDX was considered as a surface characterization technique.

\subsection{Nitric oxide loading}

NO loading (adsorption) of NZ was performed under a continuous flow of $20 \mathrm{~mL} \mathrm{~min}{ }^{-1} \mathrm{NO}$ (Linde, $99.5 \%$ ) at $30{ }^{\circ} \mathrm{C}$. Approximately $0.7 \mathrm{~g}$ of NZ was packed into a stainless steel column and activated at $400{ }^{\circ} \mathrm{C}$ for $12 \mathrm{~h}$ prior to the adsorption. The column outlet flow composition was recorded continuously as a function of time using a thermal conductivity detector (TCD) operating at $250{ }^{\circ} \mathrm{C}$ equipped with the gas chromatograph (6890 N, Agilent Technologies). After the detector signal had reached a constant value, the inlet NO flow was switched to pure helium of $20 \mathrm{~mL} \mathrm{~min}^{-1}$ until the detector signal turned back to the baseline in order to remove the gas-phase and weakly (reversibly) adsorbed species. The flow rates of the gases were controlled by mass flow controllers calibrated for each gas (5850S, Brooks Instruments) and a processor (Read and Out Control Electronics 0152, Brooks Instruments). Following the purging with pure helium, the zeolite was either depacked from the column and stored in a dry atmosphere or subjected to the in situ temperature-programmed desorption (TPD) by increasing the oven temperature to $400{ }^{\circ} \mathrm{C}$ at a heating rate of

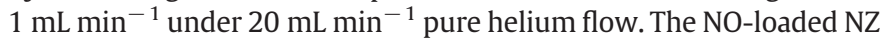
particles (NZ-NO) were kept in 12-mL gas-tight amberlite glass vials in a molecular sieve $4 \mathrm{~A}$ desiccator at room temperature. The total and reversibly adsorbed amounts of NO were determined from the adsorption and desorption breakthrough curves, respectively. The irreversibly adsorbed amount was determined from the difference between the total and reversibly adsorbed amounts.

The zeolite samples subjected to the helium purging following the NO loading and subjected to the TPD were labeled as "NZ-NO" and "NZ-NO-Des", respectively.

\subsection{Nitric oxide release characteristics}

NO storage and release properties of NZ particles were evaluated in terms of the antibacterial and bactericidal activity of the NO-loaded NZ particles under physiological conditions (water, phosphatebuffered saline $\mathrm{pH} 7.4$, at $37^{\circ} \mathrm{C}$ ).

\subsubsection{Antibacterial activity of NO-loaded zeolite}

The antibacterial tests were performed using agar-well diffusion assay. The antibacterial activity of NO-loaded NZ was tested against the reference strains of Escherichia coli (NRLLB 3008) and Bacillus subtilis (NRLLB 4378) as representatives for Gram-negative and Grampositive bacteria, respectively. The standardized bacteria cells were inoculated into nutrient broth and left to incubate overnight at $37^{\circ} \mathrm{C}$. The final cell concentrations of the overnight-grown cultures of $E$. coli and $B$. subtilis contain $\sim 10^{9} \mathrm{cfu} \mathrm{mL}^{-1}$ and $\sim 10^{7} \mathrm{cfu} \mathrm{mL}^{-1}$, respectively. The viable cell concentrations of the stock $E$. coli and B. subtilis cultures were confirmed by plating the $1 \mathrm{~mL}$ from the appropriate dilutions according to the pour plate method.

For the antibacterial activity tests, $19 \mathrm{~mL}$ of Mueller-Hinton agar was inoculated with $0.5 \mathrm{~mL}$ of the overnight-grown bacterial strains. The inoculated agar was then poured into Petri dishes and allowed to set. Maximum four wells ( $5.5 \mathrm{~mm}$ diameter) were made in each plate with a sterile cork borer and the agar was removed with sterile forceps under aseptic conditions. The wells were filled with approximately $40 \mathrm{mg}$ of the NO-loaded NZ particles. The agar plate was then covered with a lid and incubated at $37^{\circ} \mathrm{C}$ for $24 \mathrm{~h}$. The antibacterial activities were tested in at least triplicate and expressed in terms of the average diameter of the growth zone inhibition. The zone of inhibition around each well was measured with a micrometer. The average diameters were normalized with respect to the zeolite mass filled to the well. The absence of a growth inhibitory zone for the bacteria around the well was interpreted as the absence of antibacterial activity. A clear inhibition zone represents antibacterial properties and the diameter of inhibition indicates the strength of the antibacterial properties. The antibacterial properties of $\mathrm{NZ}$ and of NZ subjected to the thermal treatment following the NO loading (NZ-NO-Des) were also tested as controls. The stability of the antibacterial activity of NO-loaded NZ was examined using the NZ-NO particles stored in a gas-tight vial under dry atmosphere for different time periods.

\subsubsection{Bactericidal properties of NO-loaded zeolite}

The effect of NO loading on the bactericidal activity of NZ was tested against E. coli and B. subtilis. Different amounts of NZ-NO (500, 250,100 and $5 \mathrm{mg}$ ) were contacted with $20 \mathrm{~mL}$ of phosphate buffer saline ( $5 \mathrm{mM}$ PBS, pH 7.4) for $2 \mathrm{~h}$ at $37^{\circ} \mathrm{C}$ under $80 \mathrm{rpm}$ stirring in a thermoshaker (Max-Q 4000, Lab-Line, Barnstead). The PBS was sterilized by filtering through a $0.45-\mu \mathrm{m}$ sterile filter (Millipore) just prior to use. At the end of the contact period, $1 \mathrm{~mL}$ samples were taken from the supernatants and poured on to the nutrient agar. After 48-hour incubation at $37^{\circ} \mathrm{C}$, the viable cells were counted. The bacterial concentrations of the $E$. coli and B. subtilis stock cultures were also determined in each experimental set by serial dilutions and found to be in the range of $7.2-13.9 \times 10^{8} \mathrm{cfu} \mathrm{mL}^{-1}$ and 2.8 $3.7 \times 10^{7} \mathrm{cfu} \mathrm{mL}^{-1}$, respectively. The initial $E$. coli and B. subtilis bacterial loads in the PBS were adjusted to $7200-13900 \mathrm{cfu} \mathrm{mL}^{-1}$ and $2800-3700 \mathrm{cfu} \mathrm{mL}^{-1}$ of $E$. coli and B. subtilis, respectively. The bactericidal activities of NZ and NZ-NO-Des against both bacteria were also tested at the highest zeolite/PBS ratio as controls in order to elucidate the effect of the released NO on the bactericidal activity.

\subsubsection{Nitric oxide release kinetics in PBS}

In order to determine whether there is a correlation between the amount of NO released and the bactericidal activity, different amounts of NZ-NO were contacted with the PBS $\left(0.25-25 \mathrm{mg} \mathrm{mL}^{-1}\right)$ under the same conditions for which the bactericidal tests were performed. The total nitrite concentration in the buffer solution was taken to be equivalent to the NO released from the particles during each time period. The nitrite concentration was determined via the Griess spectrophotometric method (Green et al., 1982; Schmidt and Kelm, 1996; Privat et al., 1997). $50 \mu \mathrm{L}$ samples were taken from the supernatants at 30 min time intervals and reacted with $50 \mu \mathrm{L}$ Griess reagent ( $1 \%$ sulfanilamide in $5 \%$ phosphoric acid and $0.1 \% \mathrm{~N}-(1-$ naphthyl) ethylenediamine dihydrochloride in water) in a 96-well plate. Then, the solution was incubated for $10 \mathrm{~min}$ at room temperature, protected from light. A purple/magenta color formed 
immediately. The absorbance values at $525 \mathrm{~nm}$ were recorded using an UV-visible spectrometer (Multiskan Spectrum, Thermo Electron Corporation). The measurement of nitrite by the Griess reagent technique as a marker for NO release has been well established in the literature (Wink et al., 1993; Lewis and Deen, 1994; Goldstein and Czapski, 1995). The calibration was performed on nitrite standards prepared by dissolving $\mathrm{NaNO}_{2}$ in the PBS and diluted to between 0 and $100 \mu \mathrm{M}$. The data were then collected over time and correlated with the calibration data, resulting in the NO concentration in the PBS over time. The NO release measurements in PBS were also performed using NZ and NZ-NO-Des samples at the highest zeolite concentration in the PBS, i.e., $25 \mathrm{mg} \mathrm{mL}^{-1}$.

\subsubsection{Nitric oxide release kinetics in deionized water}

Approximately $50 \mathrm{mg}$ of the NZ-NO was contacted with $100 \mathrm{~mL}$ deionized water in $100-\mathrm{mL}$ closed Schott bottles at $37^{\circ} \mathrm{C}$ without shaking. Following the addition of the NZ-NO particles into the deionized water, $50 \mu \mathrm{L}$ samples were taken from the supernatants at discrete time intervals. The amount of NO released was also measured by the Griess spectrophotometric method. The calibration was performed on nitrite standards prepared by dissolving $\mathrm{NaNO}_{2}$ in the deionized water and diluted to between 0 and $100 \mu \mathrm{M}$. Measurements were recorded at discrete intervals until the NO release was no longer detectable, i.e., the nitrite concentration in the deionized water or PBS was less than the detection limit (below $1 \mu \mathrm{M})$. NO-loaded NZ used in the release experiment was labeled as "NZ-NO-Rel".

\subsubsection{Infrared spectroscopy}

The infrared spectra of NZ, NZ-NO, NZ-NO-Des, and NZ-NO-Rel were recorded in transmittance mode. The samples for the analysis were prepared according to the standard potassium bromide ( $\mathrm{KBr}$ ) pellet method. The transmission infrared spectra were recorded in the region of $400-4000 \mathrm{~cm}^{-1}$ at room temperature after 256 scans at $2 \mathrm{~cm}^{-1}$ resolution using a spectrometer equipped with a DTGS-TEC detector (FTS 3000MX, Excalibur Series, Digilab) at room temperature. For the quantitative analysis, the absorbance values were normalized with respect to the zeolite amount in the pellet and with respect to the absorbance of the most intense band in the spectrum.

\section{Results and discussion}

\subsection{Characterization of the natural zeolite}

\subsubsection{Powder X-ray diffraction analysis}

The X-Ray powder diffractogram of NZ is shown in Fig. 1. The most intense peaks occurred at $2 \theta=9.82^{\circ}, 11.13^{\circ}, 22.36^{\circ}$ and $30.08^{\circ}$, which

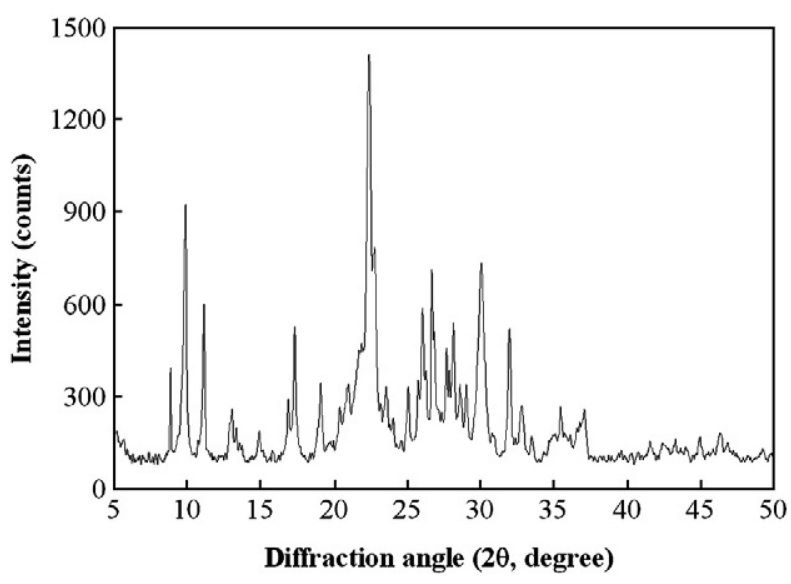

Fig. 1. XRD diffractogram of NZ. belong to the clinoptilolite phase. The qualitative mineralogical analysis revealed that NZ contains predominantly clinoptilolite (JCPDS 25-1349) as well as quartz, feldspars (microcline and sanidine), and biotite as mineral impurities. The clinoptilolite content of NZ was determined as $67 \%$ by weight (Nakamura et al., 1992). No significant changes were detected in the intensity and position of the reflections characteristic for clinoptilolite after the activation procedure applied prior to the NO loading.

\subsubsection{Elemental analysis}

The bulk elemental composition of $\mathrm{NZ}$ given in Table 1 revealed that $\mathrm{NZ}$ is rich in potassium and has a $\mathrm{SiO}_{2} / \mathrm{Al}_{2} \mathrm{O}_{3}$ ratio of 5.90 which is typical for the clinoptilolite (Tsitsishvili et al., 1992; Langella et al., 2000; Rivera-Garza et al., 2000). The theoretical cation exchange capacity (TCEC) was calculated based on the sum of the exchangeable cations $\left(\mathrm{Ca}^{2+}, \mathrm{Mg}^{2+}, \mathrm{Na}^{+}\right.$, and $\left.\mathrm{K}^{+}\right)$as 2.09 meq $\mathrm{g}^{-1}$.

\subsubsection{Scanning electron microscopy-Energy dispersive X-ray analysis (SEM-EDX)}

In the SEM micrographs of NZ shown in Fig. 2, well-defined clinoptilolite crystals of tabular, platy morphology were observed on the surface as well as in the inner parts of the particles. The average crystal size was found to be about $5 \mu \mathrm{m}$.

The surface chemical composition of NZ determined by the EDX analysis is given in Table 2 together with the bulk chemical composition. The surface and bulk elemental compositions of NZ were found to be not significantly different from each other.

\subsection{Nitric oxide loading}

The total, reversible and irreversible adsorption capacities of NZ for NO were determined from the adsorption and desorption breakthrough curves as $8.48,1.78$ and $6.71 \mathrm{mmol} \mathrm{g}^{-1}$, respectively. The percent contribution of the irreversible adsorption capacity to the total adsorption capacity was found to be about $80 \%$. Assuming that the density of the adsorbed NO is equal to its liquid density at the adsorption temperature, i.e., $0.532 \mathrm{~g} \mathrm{~cm}^{-3}$, the volume of total, reversible and irreversible adsorption capacities were determined as $0.478,0.100$ and $0.378 \mathrm{~cm}^{3} \mathrm{~g}^{-1}$, respectively.

\subsection{Nitric oxide release characteristics}

\subsubsection{Antibacterial activity of NO-loaded zeolite}

The results of the antibacterial activity tests against E. coli and B. subtilis were presented in Fig. 3. NZ did not exhibit antibacterial activity, but after NO loading it exhibited antibacterial activity against both bacteria. The thermal treatment employed subsequent to the NO loading caused the antibacterial activity to be lost which might be attributed to the desorption of the adsorbed species responsible for the antibacterial activity. When NO-NZ was stored in a gas-tight vial for different time periods, no significant loss in the strength of antibacterial activity against both bacteria was observed at least for 6 weeks.

Table 1

Bulk elemental composition of NZ (\% oxide weight).

\begin{tabular}{lc}
\hline Element in oxide form & Weight (\%) \\
\hline $\mathrm{SiO}_{2}$ & 76.62 \\
$\mathrm{Al}_{2} \mathrm{O}_{3}$ & 12.99 \\
$\mathrm{~K}_{2} \mathrm{O}$ & 5.12 \\
$\mathrm{Na}_{2} \mathrm{O}$ & 1.85 \\
$\mathrm{CaO}$ & 1.49 \\
$\mathrm{MgO}$ & 0.44 \\
$\mathrm{Fe}_{2} \mathrm{O}_{3}$ & 1.49 \\
\hline
\end{tabular}



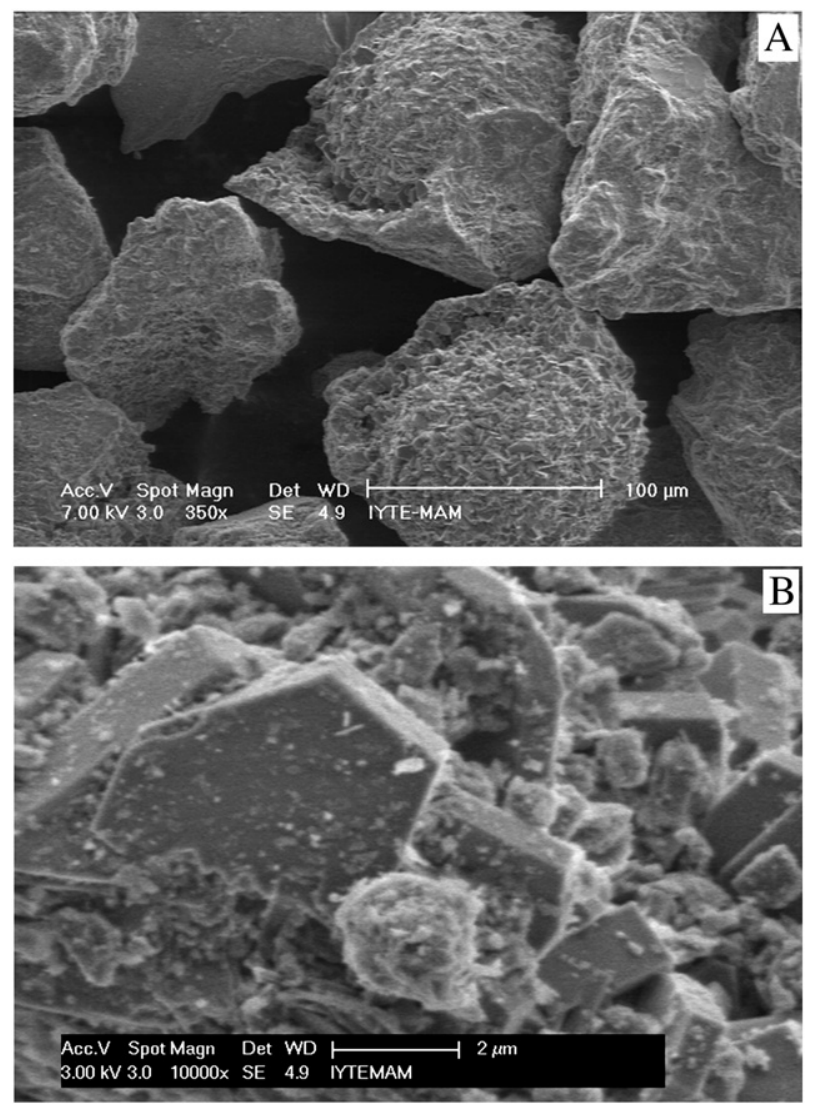

Fig. 2. SEM micrographs of $\mathrm{NZ}$ (scale bars are $100 \mu \mathrm{m}$ and $2 \mu \mathrm{m}$ for $\mathrm{A}$ and $\mathrm{B}$, respectively).

\subsubsection{Bactericidal activity of NO-loaded zeolite}

The change in the bacterial viability as a function of the mass of zeolite contacted with the PBS is shown Fig. 4. No bactericidal affect of NZ was observed, but it showed bactericidal activity after NO loading against both bacteria. NZ-NO exhibited a complete bactericidal effect on $E$. coli and B. subtilis above the NZ-NO concentration of $12.5 \mathrm{mg} \mathrm{mL}^{-1}$ and $7.5 \mathrm{mg} \mathrm{mL}^{-1}$ in PBS, respectively. The difference in the activity against the two types of bacteria might be attributed to a different organization of the cell walls. This reason was also proposed to explain the different bactericidal activity of the silver-zeolite on the Gram-positive and Gram-negative bacteria in the literature (Viarengo, 1985; Silver, 1992; Rivera-Garza et al., 2000). The bactericidal activity of NZ has vanished after the thermal treatment employed following the NO loading.

\subsubsection{Nitric oxide release kinetics in PBS}

The calibration curve constructed for the nitrite concentration measurements in PBS by dissolving $\mathrm{NaNO}_{2}$ in PBS $(0-100 \mu \mathrm{M})$ gave a good linear regression $\left(r^{2}=0.999\right)$. The change in nitrite concentra-

Table 2

Surface and bulk elemental compositions of NZ (\% weight).

\begin{tabular}{lcc}
\hline Element & Surface (EDX) & Bulk (ICP-AES) \\
\hline $\mathrm{Si}$ & $64.93 \pm 1.04$ & 70.67 \\
$\mathrm{Al}$ & $13.98 \pm 1.00$ & 13.57 \\
$\mathrm{~K}$ & $8.99 \pm 1.07$ & 8.38 \\
$\mathrm{Na}$ & $2.51 \pm 0.34$ & 2.71 \\
$\mathrm{Ca}$ & $4.80 \pm 1.46$ & 2.10 \\
$\mathrm{Fe}$ & $3.84 \pm 1.63$ & 2.05 \\
$\mathrm{Mg}$ & $0.95 \pm 0.41$ & 0.52 \\
\hline
\end{tabular}

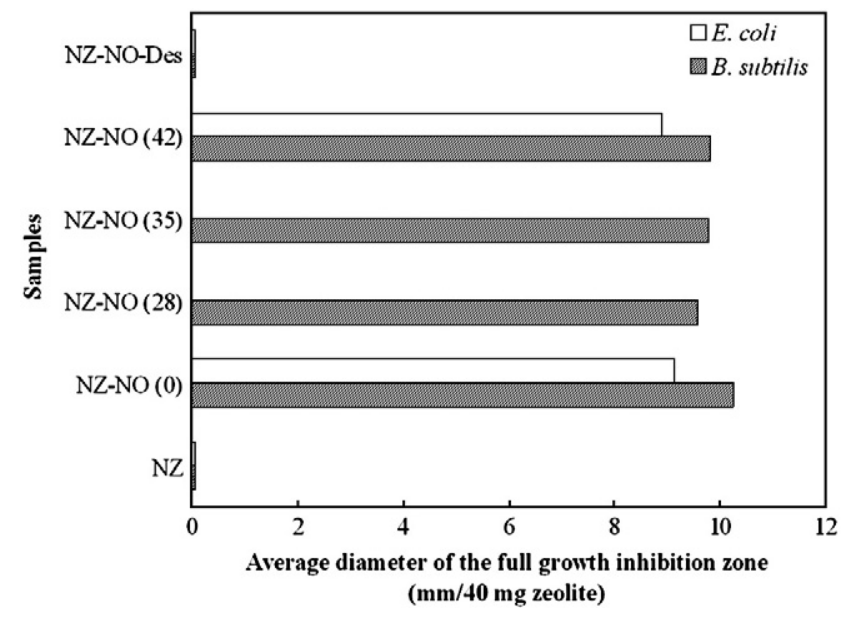

Fig. 3. Antibacterial activity of NZ, NZ-NO, and NZ-NO-Des against E. coli and B. subtilis (the numbers in the parentheses refer to the time passed after NO loading in days).

tion in PBS as a function of the amount of NZ-NO added to the PBS is shown in Fig. 5. The contact of NZ-NO with PBS induced the nitrite concentration in PBS to increase immediately. NZ-NO released most of the NO within the first 60 min of contact. The increase in nitrite concentration was more gradual after $180 \mathrm{~min}$. The amount of NO released increased with the mass of NZ-NO added to the PBS and was found to be in the range of $0.17-0.33 \mathrm{mmol} \mathrm{g}^{-1}$. Comparing with the

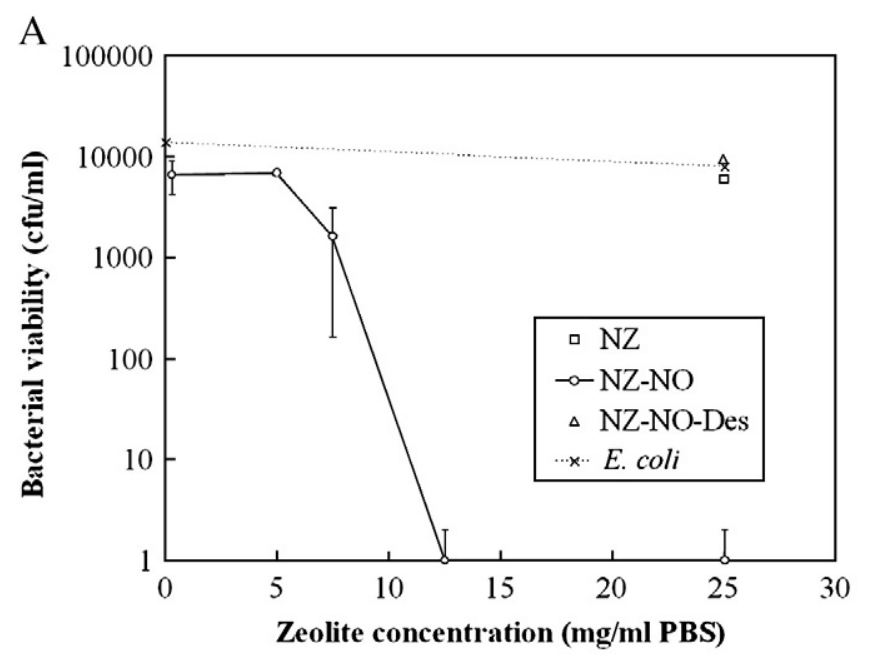

B

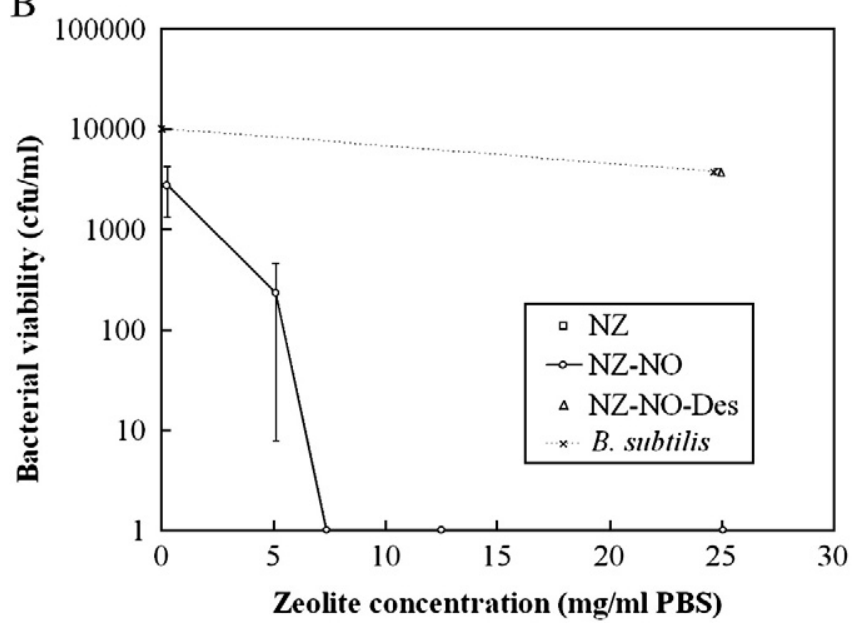

Fig. 4. Bactericidal activity of NZ-NO (in $\mathrm{PBS} \mathrm{pH} 7.4,37^{\circ} \mathrm{C}$ ) against $E$. coli (A) and B. subtilis (B). 


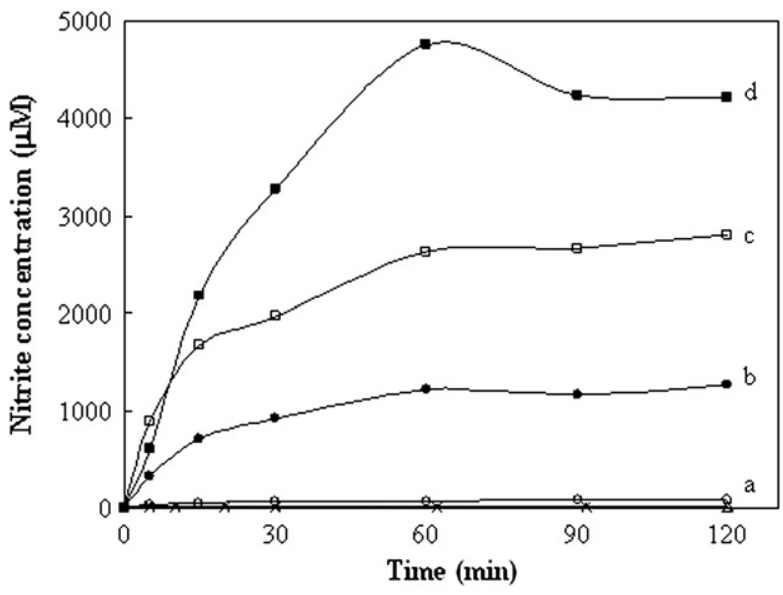

Fig. 5. Cumulative NO release profiles for NZ, NZ-NO, and NZ-NO-Des in PBS $\left(37^{\circ} \mathrm{C}, \mathrm{pH}\right.$ 7.4). The NZ-NO/PBS concentrations (in $\mathrm{mg} \mathrm{mL}^{-1}$ ) are 0.25 (a), 5.0 (b), 12.5 (c), and 25.0 (d).

amount of irreversibly adsorbed NO determined from the dynamic adsorption studies, it was revealed that the amount of released NO was about 30 times lower than the amount of irreversibly adsorbed NO. This can be explained by loss of the stored NO due to exposure of the particles to the atmosphere during weighing prior to the release experiments. NZ and NZ-NO-Des exhibited very low absorbance with the Griess assay corresponding to 10.64 and $11.79 \mu \mathrm{M}$ nitrite concentration at the end of the contact period, respectively.

\subsubsection{Nitric oxide release kinetics in deionized water}

The calibration curve prepared by dissolving $\mathrm{NaNO}_{2}$ in deionized water for the determination of the nitrite concentrations in the deionized water gave a good linear regression $\left(r^{2}=0.999\right)$. The change in the cumulative nitrite concentration in the deionized water upon contact of NZ-NO is shown in Fig. 6. NZ-NO released most of the loaded NO within the first 240 min of contact. The change in nitrite concentration in the deionized water after $240 \mathrm{~min}$ was negligible. The half-life of NO release was determined as $10 \mathrm{~min}$. The total amount of NO released from NZ-NO was found to be $0.22 \mathrm{mmol} \mathrm{g}^{-1}$. The cumulative release profiles for the same zeolite loaded with NO three and five months ago were also shown in the inset of the figure and the first $180 \mathrm{~min}$ of the releases were compared with the profile for the freshly loaded zeolite. The total amounts of NO released were found as 0.061 and $0.005 \mathrm{mmol} \mathrm{g}^{-1}$ zeolite for NZ-NO loaded 3 months and 5 months before the release experiments, respectively.

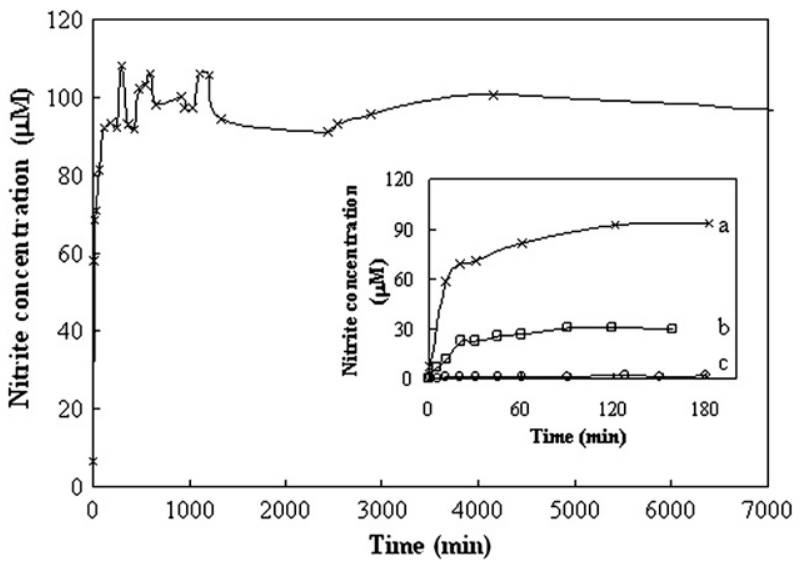

Fig. 6. Cumulative NO release profile for NZ-NO in deionized water $\left(37^{\circ} \mathrm{C}\right)$. The NO loading was performed on the same day of the release measurements (a), 3 months ago (b), and 5 months ago (c).
After 3 months, the amount of released NO decreased approximately by $70 \%$, and after 5 months by $97 \%$. NZ and NZ-NO-Des samples exhibited no signal with the Griess assay (not shown).

The NO release kinetics from NZ-NO particles was described by the Fick's second law of diffusion:

$\frac{\partial q}{\partial t}=\frac{1}{R_{p}^{2}} \frac{\partial}{\partial R}\left(R^{2} D_{N O} \frac{\partial q}{\partial R}\right)$

where $q$ is the concentration of NO in the zeolite particle, $D_{N O}$ is the effective diffusivity of $\mathrm{NO}$ within the zeolite particle and $R$ is the radial coordinate within the particle. Assuming constant diffusion coefficient which is valid at low concentrations of NO, Eq. (1) becomes:

$\frac{\partial q}{\partial t}=\frac{D_{N O}}{R_{p}^{2}} \frac{\partial}{\partial R}\left(R^{2} \frac{\partial q}{\partial R}\right)$

For the following initial and boundary conditions:

at $\mathrm{t}=0, \mathrm{q}=\mathrm{M}_{\mathrm{e}}$

for $\mathrm{t}>0$ and at $\mathrm{R}=\mathrm{R}_{\mathrm{p}}, \mathrm{q}=\mathrm{M}_{\mathrm{t}}$

for $\mathrm{t}>0,\left(\frac{\partial q}{\partial R}\right)_{R=0}=0$.

The solution for Eq. (2) is given by (Crank, 1979):

$\frac{M_{t}}{M_{e}}=1-\frac{6}{\pi^{2}} \sum_{n=1}^{\infty} \frac{1}{n^{2}} \exp \left(-\frac{n^{2} \pi^{2} D_{N O} t}{R_{p}^{2}}\right)$

where $M_{t}$ and $M_{e}$ are the cumulative amounts of NO released at time $t$ and at equilibrium, respectively, and $R_{p}$ is the particle radius. It was assumed that the NO is homogeneously distributed throughout the zeolite initially (before the NO-loaded zeolite is exposed to the release medium).

Approximate solution for the initial region of the diffusion is obtained by neglecting the higher terms:

$\frac{M_{t}}{M_{e}} \approx \frac{6}{\sqrt{\pi}} \sqrt{\frac{D_{N O} t}{R_{p}^{2}}}$.

In the long time region, all terms except the first in the series of exponential terms in Eq. (4) become negligible so that the release curve approaches the asymptotic form:

$\frac{M_{t}}{M_{e}} \approx 1-\frac{6}{\pi^{2}} \exp \left(-\frac{\pi^{2} D_{N O} t}{R_{p}^{2}}\right)$.

The diffusion coefficient of NO in the zeolite particle was determined by fitting the short time approximate solution (Eq. (5)) to the experimental NO release kinetics data. From the plots shown in Fig. 7, the diffusion coefficients were calculated are given in Table 3.

The experimental kinetic data for NO release in deionized water was also analyzed in the same manner. The plot in Fig. 8 shows fitting of the analytical solution of the model to the experimental NO release data for NZ-NO. Good agreement was obtained $\left(r^{2}=0.898\right)$ and the diffusion coefficient $\left(D_{N O}\right)$ was calculated as $7.84 \times 10^{-10} \mathrm{~cm}^{2} \mathrm{~s}^{-1}$.

Changes in the color of NZ were observed upon NO loading and thermal treatment applied successive to the NO loading. The color of NZ turned from beige to yellowish after NO loading and to darker yellow after the thermal treatment. After contacting NZ-NO with either PBS or deionized water, the color turned to that at the initial stage. The color changes are indication of interactions of NO molecules with the coordinatively unsaturated metal sites during the NO loading and replacement of these by metal-water interactions during the 
A

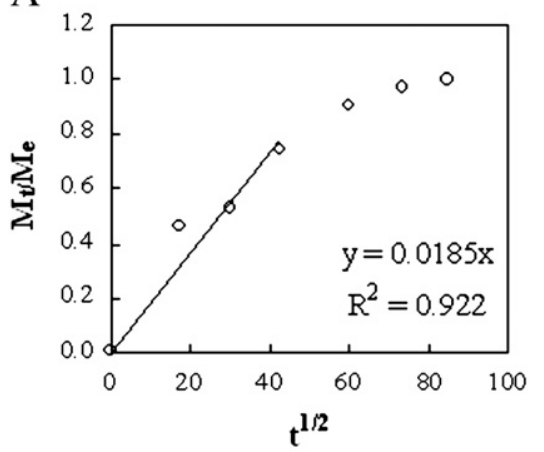

$\mathrm{C}$

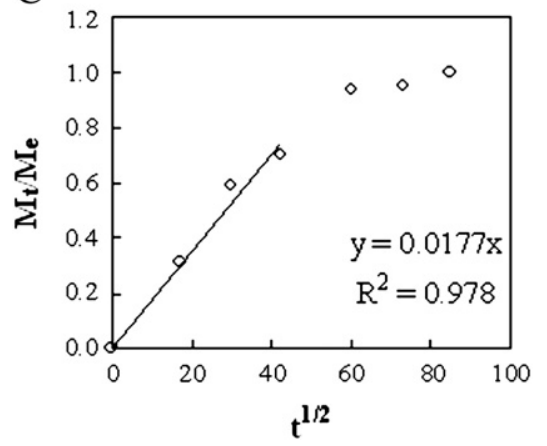

B

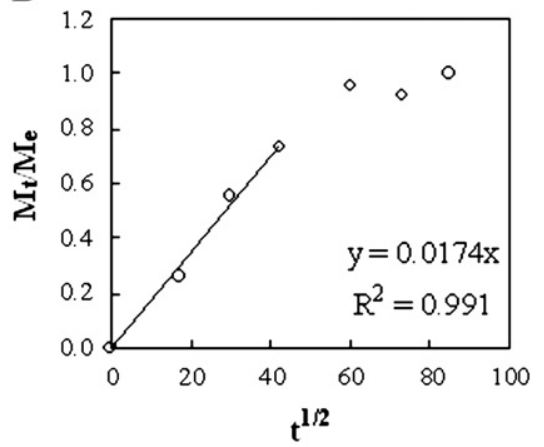

D

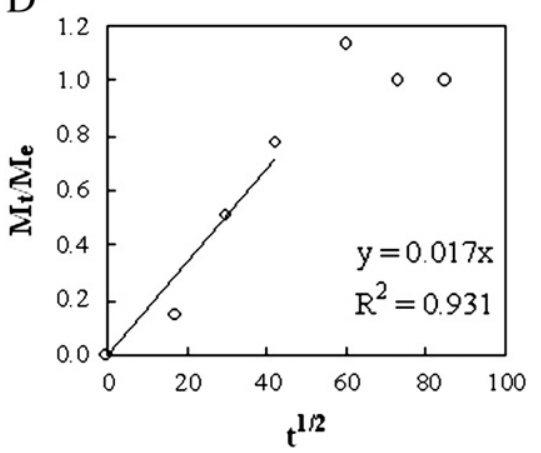

Fig. 7. NO release kinetics from NZ-NO in PBS for NZ-NO/PBS concentrations (in $\mathrm{mg} \mathrm{mL}^{-1}$ ) of 0.25 (A), 5.0 (B), 12.5 (C), and 25.0 (D).

release (Padden et al., 2001; Wheatley et al., 2006; McKinlay et al., 2008).

\subsubsection{Infrared spectroscopy}

The FTIR spectra of NZ, NZ-NO, NZ-NO-Des and NZ-NO-Rel are presented in Fig. 9. In the spectrum of NZ, the bands detected in the range of $1200-400 \mathrm{~cm}^{-1}$ are assigned to the internal stretching vibrations of $\mathrm{Si}-\mathrm{O}(\mathrm{Si})$ and $\mathrm{Si}-\mathrm{O}(\mathrm{Al})$ in the tetrahedra. The strongest T-O stretching vibration which appeared at $1058 \mathrm{~cm}^{-1}$ with a shoulder at $1207 \mathrm{~cm}^{-1}$ was attributed to asymmetric O-T-O stretching vibration and is sensitive to the $\mathrm{Si}$ and $\mathrm{Al}$ content of the framework. The vibrations in the region $1600-3700 \mathrm{~cm}^{-1}$ can be assigned to the presence of zeolite water. In the $\mathrm{OH}$ stretching region (3000-3700 $\left.\mathrm{cm}^{-1}\right)$, the isolated $\mathrm{OH}$ stretching vibration band $\left(3611 \mathrm{~cm}^{-1}\right)$ is attributed to interaction between the water hydroxyl and the cations present in NZ. The other band at $3448 \mathrm{~cm}^{-1}$ is attributed to the hydrogen bonding of the water molecule to surface oxygen. An isolated absorption band at $1635 \mathrm{~cm}^{-1}$ is due to bending vibrations of sorbed water ( $\mathrm{H}-\mathrm{O}-\mathrm{H}$ bending). When the zeolite is fully activated this band disappears (Breck, 1974).

A sharp band at $1385 \mathrm{~cm}^{-1}$ appeared in the spectrum of NZ after NO loading. The intensity of this band appreciably decreased after heating of NZ-NO to $400{ }^{\circ} \mathrm{C}$ successive to the NO loading. It almost disappeared after NZ-NO was contacted with water. This band is close to the band at $1400 \mathrm{~cm}^{-1}$ which is assigned to $\mathrm{NO}_{3}^{-}$species induced upon adsorption of NO on different zeolites (Nakamoto, 1966; Chao

Table 3

The diffusion coefficients calculated for the NO release from NZ-NO in phosphate buffer saline.

\begin{tabular}{ll}
\hline NZ-NO/PBS $\left(\mathrm{mg} \mathrm{ml}^{-1}\right)$ & $\mathrm{D}_{\mathrm{NO}}\left(\mathrm{cm}^{2} \mathrm{~s}^{-1}\right)$ \\
\hline 0.25 & $8.87 \times 10^{-10}$ \\
5.0 & $7.84 \times 10^{-10}$ \\
12.5 & $8.12 \times 10^{-10}$ \\
25.0 & $7.49 \times 10^{-10}$ \\
\hline
\end{tabular}

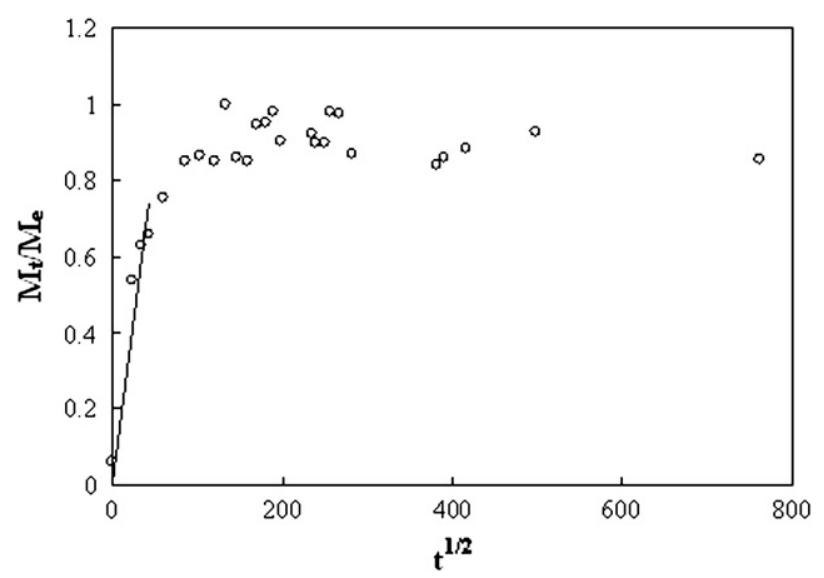

Fig. 8. NO release kinetics for NZ-NO in deionized water (NZ-NO/deionized water: $50 \mathrm{mg} / 100 \mathrm{~mL}$ ).

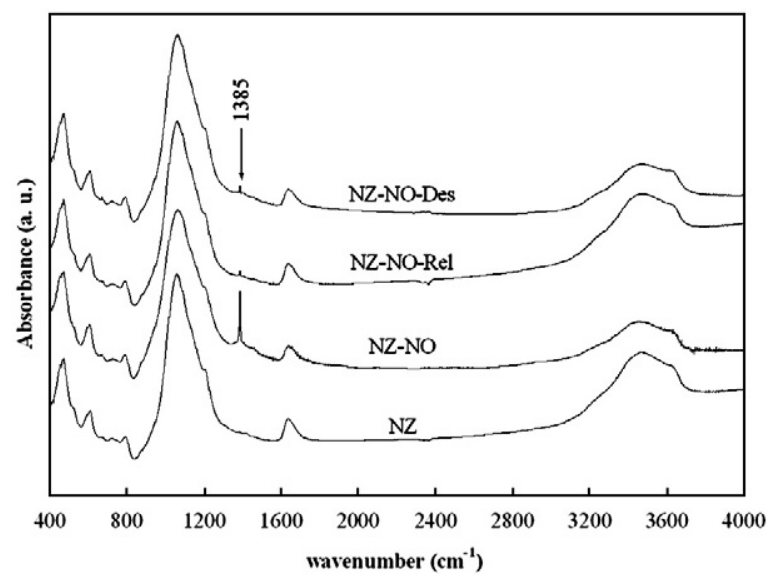

Fig. 9. FTIR spectra of NZ, NZ-NO, NZ-NO-Des, and NZ-NO-Rel. 
and Lunsford, 1971). The formation of nitrate species in the absence of oxygen in the feed stream was explained by the involvement of the lattice oxygen in the transition metal oxides in the reaction (Laane and Ohlsen, 1980; Pinna, 1998; Huang and Yang, 2001; Ivanova et al., 2001; Salama et al., 2005).

\section{Conclusions}

In the present study, possible utilization of local clinoptilolite-rich natural zeolite (NZ) in nitric oxide (NO) adsorption, storage and release for medical purposes was investigated. NZ adsorbed NO reversibly and irreversibly at $30{ }^{\circ} \mathrm{C}$. The total, reversible and irreversible desorption capacities of NZ for NO were determined as $8.48,1.78$ and $6.71 \mathrm{mmol} \mathrm{g}^{-1}$, respectively. The percent contribution of the irreversible adsorption capacity to the total adsorption capacity was found to be about $80 \%$. NZ gained antibacterial and bactericidal activities against both Gram-negative (Escherichia coli) and Grampositive bacteria (Bacillus subtilis) after NO loading. The antibacterial activity against both bacteria was found to be stable for at least 6 weeks, without loss in the strength, when NZ was stored in gas-tight vials under a dry atmosphere immediately after the NO loading. The bactericidal effect was observed against $E$. coli and $B$. subtilis when the NO-loaded NZ was contacted in concentrations higher than 12.5 and $7.5 \mathrm{mg}$ zeolite/mL PBS, respectively. The antibacterial and bactericidal activities vanished after the NO-loaded NZ was subjected to the thermal treatment successive to the NO loading. The amount of NO released per unit weight of NO-loaded NZ in the PBS was found to be in the range of $0.17-0.33 \mathrm{mmol} \mathrm{g}^{-1}$. This was about 30 times lower than the irreversibly adsorbed amount of NO. The total amount of NO released from the freshly NO-loaded NZ in deionized water was found to be approximately $0.22 \mathrm{mmol} \mathrm{g}^{-1}$. The total amount of NO released after three and five months of the NO loading decreased remarkably. The NO-loaded NZ exhibited similar NO release kinetics in deionized water and PBS. The release of NO from NZ-NO continued for $300 \mathrm{~min}$. No NO release was detected for NZ and for the NO-loaded NZ thermally treated successive to the NO loading. The color of NZ changed upon NO loading, successive thermal treatment and upon contact of the NO-loaded NZ with water or PBS. The color changes were explained by the metal-NO interactions during the storage of NO and the replacement of these by metal-water interactions on delivery. In the IR spectrum of the NO-loaded NZ, a strong band was detected at $1385 \mathrm{~cm}^{-1}$. This band either lost intensity or disappeared in the spectrum of the NO-loaded $\mathrm{NZ}$ after heated to $400{ }^{\circ} \mathrm{C}$ or after it was contacted with water or PBS.

In summary, it was shown that the local clinoptilolite-rich natural zeolite could adsorb NO reversibly and irreversibly. The irreversibly adsorbed NO could be stored under dry atmosphere and was released when contacted the NO-loaded NZ with aqueous medium under physiological conditions. The released NO exhibited antibacterial and bactericidal activities against both Gram-positive and Gram-negative bacteria. Hence, the local clinoptilolite-rich natural zeolite seems a promising adsorbent for NO storage and release for medical applications. The toxicology of zeolites has been extensively studied and the zeolites are regarded as benign materials. On the other hand, prolonged exposure to NO at elevated concentrations is associated with many detrimental physiological conditions including septic shock, apoptosis, cytotoxicity, DNA damage, and carcinogenesis. Hence, the implications of NO release on the neighboring tissue should be investigated. In a recent study, inflammatory properties of NO delivered through an inert topical NO donor NO-loaded zeolite (Ze-NO), were compared those of topical NO donor acidified nitrite $\left(\mathrm{NO}_{2}\right)$. It was shown that using the Ze-NO as NO donor, NO per se caused little inflammation. Clinical inflammation was observed at the sites of acidified $\mathrm{NO}_{2}$ application with significant discomfort, erythema, edema, and superficial cutaneous ulceration. There were no clinically visible changes or discomfort consistent with inflamma- tion for the Ze-NO. Acidified $\mathrm{NO}_{2}$, but not Ze-NO, caused infiltration of macrophages and neutrophils into the epidermis. It was concluded that Ze-NO is an effective NO donor without the dramatic proinflammatory effects that were previously attributed to NO (Mowbray et al., 2008).

\section{Acknowledgements}

This study was financially supported by Turkish Republic Prime Ministry State Planning Organization (DPT-2006K120690, Determination of Effects of Zeolite on Health on Cellular and Molecular Level). The clinoptilolite standard minerals were kindly supplied by F. Mumpton from Mineral Research, Clarkson, New York.

\section{References}

Akdeniz, Y., Ülkü, S., 2007. Microwave effect on ion-exchange and structure of clinoptilolite. J. Porous Mat. 14, 55-60.

Akdeniz, Y., Ülkü, S., 2008. Thermal stability of Ag-exchanged clinoptilolite rich mineral. J. Therm. Anal. Calorim. 94, 703-710.

Breck, D.W., 1974. Zeolite molecular sieves. John Wiley and Sons, New York.

Çakıcıoğlu-Özkan, F., Ülkü, S., 2004. The effect of $\mathrm{HCl}$ treatment on water vapor adsorption characteristics of clinoptilolite rich natural zeolite. Microporous Mesoporous Mat. 77, 47-53.

Çakıcıoğlu-Özkan, F., Ülkü, S., 2008. Diffusion mechanism of water vapour in a zeolitic tuff rich in clinoptilolite. J. Therm. Anal. Calorim. 94, 699-702.

Carballo, R.S., Rodriquez-Fuentes, G., Urbina, C., Fleitas, A., 2001. Study of the reaction of a Ca-clinoptilolite and human bile. In: Galarneau, A., Di Renzo, F., Fajula, F., Védrine, J. (Eds.), Studies in surface science and catalysis, Vol. 135. Elsevier, Amsterdam, pp. 5268-5275.

Chao, C.C., Lunsford, J.H., 1971. Infrared studies of the disproportionation reaction of nitric oxide on Y-type zeolites. J. Am. Chem. Soc. 93, 71-77.

Concepción-Rosabal, B., Rodriguez-Fuentes, G., Simón-Carballo, R., 1997. Development and featuring of the zeolitic active principle FZ: a glucose adsorbent. Zeolites 19, 47-50.

Concepción-Rosabal, B., Rodríguez-Fuentes, G., Bogdanchikova, N., Bosch, P., Avalos, M., Lara, V.H., 2005. Comparative study of natural and synthetic clinoptilolites containing silver in different states. Microporous Mesoporous Mat. 28, 249-255.

Crank, J., 1979. The Mathematics of Diffusion, second ed. Clarendon Press, Oxford.

De Groote, M.A., Fang, F.C., 1995. NO inhibitions: antimicrobial properties of nitric oxide. Clin. Infect. Dis. 21 (Suppl. 2), S162-S165.

Denicola, A., Souza, J.M., Radi, R., Lissi, E., 1996. Nitric oxide diffusion in membranes determined by fluorescence quenching. Arch. Biochem. Biophys. 328 (1), 208-212.

Dobmeier, K.P., Schoenfisch, M.H., 2004. Antibacterial properties of nitric oxidereleasing sol-gel microarray. Biomacromolecules 5 (6), 2493-2495.

Esenli, F., 2002. Natural zeolite reserves, mining, production, and market situation. Zeolite Symposium. Tübitak-MAM, Gebze, Kocaeli (in Turkish). Online published. pp. $1-10$.

Fang, F.C., 1997. Mechanisms of nitric oxide-related antimicrobial activity. J. Clin. Invest. $99,2818-2825$

Fang, F.C., 2004. Antimicrobial reactive oxygen and nitrogen species: concepts and controversies. Nat. Rev. Microbiol. 2, 820-832.

Farías, T., Ruiz-Salvador, A.R., Rivera, A., 2003. Interaction studies between drugs and a purified natural clinoptilolite. Microporous Mesoporous Mat. 61, 117-125.

Fox, S., Wilkinson, S., Wheatley, P.S., Xiao, B., Morris, R.E., Sutherland, A., Simpson, A.J. Barlow, P.G., Butler, A.R., Megson, I.L., Rossi, A.G., 2010. NO-loaded $\mathrm{Zn}^{2+}$-exchanged zeolite materials: a potential bifunctional anti-bacterial strategy. Acta Biomater. 6, 1515-1521.

Fukumura, D., Jain, R.K., 1998. Role of nitric oxide in angiogenesis and microcirculation in tumors. Cancer Metast. Rev. 17, 77-89.

Ghaffari, A., Neil, D.H., Ardakani, A., Road, J., Ghahary, A., Miller, C.C., 2005. A direct nitric oxide gas delivery system for bacterial and mammalian cell cultures. Nitric Oxide $12,129-140$.

Goldstein, S., Czapski, G., 1995. Kinetics of nitric oxide autoxidation in aqueous solution in the absence and presence of various reductants. The nature of the oxidizing intermediates. J. Am. Chem. Soc. 117, 12078-12084.

Green, L.C., Wagner, D.A., Glogowski Jr., J., Skipper, P.L., Wishnok, J.S., Tannenbaum, S.R., 1982. Analysis of nitrate, nitrite, and $\left[{ }^{15} \mathrm{~N}\right]$ nitrate in biological fluids. Anal. Biochem. 126, 131-138.

Hetrick, E.M., Shin, J.H., Stasko, N.A., Johnson, C.B., Wespe, D.A., Holmuhamedov, E., Schoenfisch, M.H., 2008. Bactericidal efficacy of nitric oxide-releasing silica nanoparticles. ACS Nano 2, 235-246.

Hoehn, T., Huebner, J., Paboura, E., Krause, M., Leititis, J.U., 1998. Effects of therapeutic concentrations of nitric oxide on bacterial growth in vitro. Crit. Care Med. 26, 1857-1862.

Huang, H.Y., Yang, R.T., 2001. Removal of NO by reversible adsorption on Fe-Mn based transition metal oxides. Langmuir 17, 4997-5003.

Ivanova, E., Hadjiivanov, K., Klissurski, D., Bevilacqua, M., Armaroli, T., Busca, G., 2001. FTIR studies of species arising after $\mathrm{NO}$ adsorption and $\mathrm{NO}+\mathrm{O}_{2}$ co-adsorption on CoY: comparison with Co-ZSM-5. Microporous Mesoporous Mat. 46, 299-309. 
Kelm, M., 2003. The l-arginine-nitric oxide pathway in hypertension. Curr. Hypertens. Rep. 5, 80-86.

Kelm, M., Schrader, J., 1988. Nitric oxide release from isolated guinea pig heart. Eur. J. Pharmacol. 155, 317-321.

Kelm, M., Yoshida, K., 1996. Metabolic fate of nitric oxide and related N-oxides. In: Feelisch, M., Stamler, J.S. (Eds.), Methods in nitric oxide research. John Wiley and Sons, New York, pp. 47-58.

Laane, J., Ohlsen, J.R., 1980. Characterization of nitrogen oxides by vibrational spectroscopy. In: Lippard, S.J. (Ed.), Progress in inorganic chemistry, Vol. 27. John Wiley, New York, pp. 465-513.

Lam, A., Sierra, L.R., Rojas, G., Rivera, A., Rodriguez-Fuentes, G., Montero, L.A., 1998. Theoretical study of the physical adsorption of aspirin on natural clinoptilolite. Microporous Mesoporous Mat. 23, 247-252.

Langella, A., Pansini, M., Cappelletti, P., Gerraro, B., Gennaro, M., Collela, C., 2000. $\mathrm{NH}_{4}^{+}$ $\mathrm{Cu}^{2+}, \mathrm{Zn}^{2+}, \mathrm{Cd}^{2+}$ and $\mathrm{Pb}^{2+}$ exchange for $\mathrm{Na}^{+}$in a sedimentary clinoptilolite, North Sardinia, Italy. Microporous Mesoporous Mat. 37, 337-343.

Lewis, R.S., Deen, W.M., 1994. Kinetics of the reaction of nitric oxide with oxygen in aqueous solutions. Chem. Res. Toxicol. 7 (4), 568-574.

Mateo, A.O., De Artinano, M.A.A., 2000. Nitric oxide reactivity and mechanisms involved in its biological effects. Pharmacol. Res. 42, 421-427.

McKinlay, A.C., Xiao, B., Wragg, D.S., Wheatley, P.S., Megson, I.L., Morris, R.E., 2008. Exceptional behavior over the whole adsorption-storage-delivery cycle for NO in porous metal organic frameworks. J. Am. Chem. Soc. 130, 10440-10444.

Menzel, D.B., 1993. Antioxidants in lung disease. Toxicol. Ind. Health 9, 323-336.

Moncada, S., Palmer, R.M.J., Higgs, E.A., 1991. Endogenous nitric oxide: physiology, pathology and clinical relevance. Eur. J. Clin. Invest. 43, 109-141.

Mowbray, M., Tan, X., Wheatley, P.S., Morris, R.E., Weller, R.B., 2008. Topically applied nitric oxide induces T-lymphocyte infiltration in human skin, but minimal inflammation. J. Invest. Dermatol. 128, 352-360.

Nablo, B.J., Rothrock, A.R., Schoenfisch, M.H., 2005. Nitric oxide-releasing sol-gels as antibacterial coatings for othopedic implants. Biomaterials 26 (8), 917-924.

Nakamoto, K., 1966. Infrared spectra of inorganic and coordination compounds. Mir, Moscow.

Nakamura, T., Ishikawa, M., Hiraiwa, T., Sato, J., 1992. X-Ray diffractometric determination of clinoptilolite in zeolite tuff using multiple analytical lines. Anal. Sci. 8, 539-543.

Narin, G., 2001. A chromatographic study of carbon monoxide adsorption in clinoptilolite. M.S. Thesis, Izmir Institute of Technology. Izmir, Turkey.

Narin, G., Yılmaz, S., Ülkü, S., 2004. A chromatographic study of carbon monoxide adsorption on a clinoptilolite-containing natural zeolitic material. Chem. Eng. Commun. 191, 1411-1425.

Padden, K.M., Krebs, J.F., MacBeth, C.E., Scarrow, R.C., Borovik, S., 2001. Immobilized metal complexes in porous organic hosts: development of a material for the selective and reversible binding of nitric oxide. J. Am. Chem. Soc. 123, 1072-1079.

Parlat, S.S., Yıldız, A.O., Oğuz, H., 1999. Effect of clinoptilolite on performance of Japanese quail (Coturnix coturnix japonica) during experimental aflatoxicosis. Br. Poult. Sci. 40, 495-500.

Pavelic, K., Hadzija, M., Bedrica, L., Pavelic, J., Dikic, I., Katic, M., Krajl, M., Bosnar, M.H., Kapitonovic, S., Poljak-Blazi, M., Krizanac, S., Stojkovic, R., Jurin, M., Subotic, B., Colic, M., 2001. Natural zeolite clinoptilolite: new adjuvant in anticancer therapy. J. Mol. Med. 78, 708-720.

Pavelic, K., Katic, M., Sverko, V., Marotti, T., Bosnjak, B., Balog, T., Stojkovic, R., Radacic, M., Colic, M., Poljak-Blazi, M., 2002. Immunostimulatory effect of natural clinoptilolite as a possible mechanism of its antimetastatic ability. J. Cancer Res. Clin. Oncol. 128, 37-44.

Pinna, F., 1998. Supported metal catalysts preparation. Catal. Today 41, 129-137.

Privat, C., Lantoine, F., Bedioui, F., Brussel, E.M., Devynck, J., Devynck, M., 1997. Nitric oxide production by endothelial cells: comparison of three methods of quantification. Life Sci. 61, 1193-1202.

Riddell, D.R., Owen, J.S., 1999. Nitric oxide and platelet aggregation. Vitam. Horm. Advan. Res. App. 57, 25-48.

Rivera, A., Farías, T., 2005. Clinoptilolite-surfactant composites as drug support: a new potential application. Microporous Mesoporous Mater. 80, 337-346.
Rivera, A., Rodriguez-Fuentes, G., Altshuler, E., 1998. Characterization and neutralizing properties of a natural zeolite/ $\mathrm{Na}_{2} \mathrm{CO}_{3}$ composite material. Microporous Mesoporous Mat. 24, 51-58.

Rivera, A., Farías, T., Ruiz-Salvador, A.R., de Ménorval, L.C., 2003. Preliminary characterization of drug support systems based on natural clinoptilolite. Microporous Mesoporous Mat. 61, 249-259.

Rivera-Garza, M., Olguín, M.T., García-Sosa, I., Alcántara, D., Rodríguez-Fuentes, G. 2000. Silver supported on natural Mexican zeolite as an antibacterial material. Microporous Mesoporous Mat. 39, 431-444.

Rodriguez-Fuentes, G., Barrios, M.A., Iraizoz, A., Perdomo, I., Cedre, B., 1997. Antidiarrheic drug based on purified natural clinoptilolite. Zeolites 19, 441-448.

Salama, T.M., Mohamed, M.M., Othman, I.A., El-Shobaky, G.A., 2005. Structural and textural characteristics of Ce-containing mordenite and ZSM-5 solids and FT-IR spectroscopic investigation of the reactivity of NO gas adsorbed on them. Appl Catal. A. 286, 85-95.

Sasaki, S., Miura, T., Nishikawa, S., Yamada, K., Hirasue, M., Nakane, A., 1998. Protective role of nitric oxide in staphylococcus aureus infection in mice. Infect. Immun. 66 1017-1022.

Schmidt, H.H.H.W., Kelm, M., 1996. Determination of nitrite and nitrate by the Griess reaction. In: Feelisch, M., Stamler, J.S. (Eds.), Methods in nitric oxide research. John Wiley and Sons, Chichester, pp. 491-497.

Seidel, H., Bartko, P., Kováč, G., Pauliková, I., Nagy, O., 1997. Effects of haemoperfusion on selected indices of blood biochemistry in sheep. Acta Vet. Brno. 66, 213-218.

Silver, S., 1992. Bacterial heavy metal detoxification and resistance systems. In: Mongkolsuk, S., Lovett, P.S., Trempy, J.E. (Eds.), Biotechnology and environmental science: molecular approaches. Plenum Press, New York, pp. 109-129.

Stamler, J.S., Lamas, S., Fang, F.C., 2001. Nitrosylation: the prototypic redox-based signaling mechanism. Cell 106, 675-683.

Top, A., 2001. Cation exchange $\left(\mathrm{Ag}^{+}, \mathrm{Zn}^{2+}, \mathrm{Cu}^{2+}\right)$ behavior of natural zeolites. M.S Thesis, Izmir Institute of Technology. Izmir, Turkey.

Top, A., Ülkü, S., 2004. Silver, zinc, and copper exchange in a Na-clinoptilolite and resulting effect on antibacterial activity. Appl. Clay Sci. 27, 13-19.

Trowbridge, H.O., Emling, R.C., 1997. Inflammation: a review of the process, fifth ed. Quintessence Publishing, Chicago.

Tsitsishvili, G.V., Andronikashvili, T.G., Kirov, G.N., Filizova, L.D., 1992. Natural Zeolites Ellis Horwood, New York.

UK Surface Analysis Forum, Surface Science Techniques. Online. 2009. Available from URL: http://www.uksaf.org/tech/edx.html.

Viarengo, A., 1985. Biochemical effects of trace metals. Mar. Pollut. Bull. 16, 153-158.

Wang, C., Deen, W.M., 2003. Nitric oxide delivery system for cell culture studies. Ann. Biomed. Eng. 31, 65-79.

Wheatley, P.S., Butler, A.R., Crane, M.S., Fox, S., Xiao, B., Rossi, A.G., Megson, I.L., Morris R.E., 2006. NO-releasing zeolites and their antithrombotic properties. J. Am. Chem. Soc. $128,502-509$.

Wink, D.A., Mitchell, J.B., 1998. Chemical biology of nitric oxide: insights into regulatory, cytotoxic, and cytoprotective mechanisms of nitric oxide. Free Radical Biol. Med. 25, 34-56.

Wink, D.A., Darbyshire, J.F., Nims, R.W., Saveedra, J.E., Ford, P.C., 1993. Reactions of the bioregulatory agent nitric oxide in oxygenated aqueous media: determination of the kinetics for oxidation and nitrosation by intermediates generated in the nitric oxide/oxygen reaction. Chem. Res. Toxicol. 6, 23-27.

Witte, M.B., Barbul, A., 2002. Role of nitric oxide in wound repair. Am. J. Surg. 183 406-412.

Xiao, B., Wheatley, P.S., Morris, R.E., 2007. The adsorption, storage and release of nitric oxide using ion exchanged zeolites. In: Xu, R., Gao, Z., Chen, J., Yan, W. (Eds.), Studies in surface science and catalysis, Vol. 170A. Elsevier, Amsterdam, pp. 902-909.

Yun, H.Y., Dawson, V.L., Dawson, T.M., 1996. Neurobiology of nitric oxide. Crit. Rev. Neurobiol. 10, 291-316.

Ziche, M., Morbidelli, L., Masini, E., Amerini, S., Granger, H.J., Maggi, C.A., Geppetti, P., Ledda, F., 1994. Nitric oxide mediates angiogenesis in vivo and endothelial cell growth and migration in vitro promoted by substance P. J. Clin. Invest. 94 2036-2044. 